\title{
Cattle Grazing White Locoweed: Diet Selection Patterns of Native and Introduced Cattle
}

\author{
M.H. RALPHS, L.V. MICKELSEN, AND D.L. TURNER
}

\section{Abstract}

Cattle preference for immature white locoweed (Oxytropis sericea Nutt.) seed pods reported in a previous intensive grazing study was confirmed using free-ranging cows under natural grazing conditions. Diets were quantified by bite count. The succulent immature seed pod was palatable and preferentially selected until its supply was exhausted. Locoweed fowers or mature seed pods were not grazed and very few locoweed leaves were consumed. Native cows (born and raised on the range) and introduced 2-year-old replacement heifers (raised in another part of the state with no prior graxing experience with locoweed) consumed similar amounts of locoweed pods.

Key Words: Oxytropis sericea, silky locoweed, white pointloco, poisonous plant, habituation

Locoweed poisoning is a complex form of toxicosis. Low levels of the alkaloid swansonine in the plant $(0.007 \%$ of dry weight, Molyneux and James 1982) cause a chronic poisoning. Swainsonine inhibits the enzyme $\alpha$-mannosidase, which is essential in the metabolism of glycoproteins (Molyneux et al. 1985). Disruption of this basic biochemical process affects all body systems and results in the multiple signs of locoweed intoxication: neurological damage, infertility and abortions, emaciation, heart failure, and habituation (James et al. 1981).

The gross signs and pathological lesions of locoweed poisoning have been described (Marsh 1909, Van Kampen et al. 1978). Sheep fed specklepod locoweed (Astragalus lentiginosus Dougl.) for $20 \%$ of their diet showed neurological changes within 8 days and neurological damage within 16 days (Van Kampen and James 1970). When consumed at high elevation, locoweed is a predisposing factor causing high mountain brisket disease (James et al. 1983). However, little is known about the amount of locoweed consumed by free-ranging animals and the length of time required to cause intoxication and permanent neurological damage. Marsh (1909) reported that intoxication of cattle and horses generally occurred after 2 to 3 months of grazing white locoweed (Oxytropis sericea Nutt.). Most cattle grazed it readily in the spring when grass was sparse. Some cows contracted the "habit" and continued eating it even when grass became abundant. Others switched to grass when it became available to contracted the "habit" in subsequent years. Some cows ate varying quantities of white locoweed over a 3-year period without apparent harm. Ralphs (1987) reported that succulent immature seed pods were highly preferred by cattle. Other locoweed plant parts were not palatable and cattle did not consume mature seed pods or leaves even when grazing pressure was extremely high.

This study tested the hypothesis developed in the previous study (Ralphs 1987) that succulent immature seed pods are the only locoweed plant part palatable to cattle and voluntarily selected under natural grazing conditions. We also compared locoweed consumption between native cattle, which had grazed this locoweed infested range each summer during their lives, and introduced cattle, which had never been exposed to locoweed. It has been reported that inexperienced animals are more included to consume poisonous plants and become intoxicated when turned out on new range than are native cattle (Everist 1981, Marsh 1916).

\footnotetext{
Authors are range scientist and range technician, USDA, Agricultural Research Service, Poisonous Plant Research Laboratory, 1150 East 1400 North, Logan, Utah 84321; and associate professor, Applied Statistics, Utah State University, Logan, Utah 84322 .

Journal Paper 3267, Utah Agricultural Experiment Station.

Manuscript accepted 11 March 1987.
}

This study was conducted during the summer of 1985 on a high mountain grassland in northwestern Utah. The site was a flat mountain top at an elevation of $2,900 \mathrm{~m}$. The site supported a fairly homogenous grass/forb subalpine vegetation community. Description of the site and vegetation species composition was provided by Ralphs et al. (1986).

A 3.2-ha pasture was fenced with temporary electric fence to accommodate 8 cows for the 6 -week grazing period. Pasture size was determined by calculating a stocking rate based on an estimated use of $50 \%$ of total forage available at the beginning of the experiment. Standing crop was sampled on 11 July (prior to beginning of the study, full bloom stage of locoweed), 31 July (early locoweed seed pod stage), 13 August (after most pods had been consumed) and 27 August (end of study). Twenty $0.25 \times 1-\mathrm{m}$ quadrats were systematically located along 2 transects running the length of the pasture. Vegetation was clipped and sorted into grass, locoweed leaf, locoweed reproductive head, and other forbs. Samples were air dried in a forced air oven at $60^{\circ} \mathrm{C}$, weighed, and standing crop of each forage class was expressed as $\mathrm{kg} / \mathrm{ha}$.

Four native mature cows $(500 \mathrm{~kg})$ that had grazed this range each summer for their entire lives, and 4 introduced 2-year-old replacement heifers $(400 \mathrm{~kg}$ ) that had never been exposed to locoweed nor grazed on high mountain subalpine grasslands, were used to estimate diet composition. The introduced heifers had been raised on irrigated meadows in Cache Valley, Utah, and were held in dry lot at the USDA/ARS Poisonous Plant Research Laboratory on a ration of alfalfa/grass hay for 7 months prior to this experiment. Previous research has shown that immature locoweed seed pods are palatable and preferentially selected by native cattle on this allotment (Ralphs et al. 1986, Ralphs 1987). We expected the introduced heifers to eat white locoweed when they were exposed to it, or to eat more of the palatable pods than the native cows.

The difference in age and size of the 2 classes of experimental animals may confound diet selection data beyond what might be expected from strictly past grazing experience. However, Arnold and Dudzinski (1978) stated that only small differences have been found in diets selected by animals of the same breed but differing in age. Non-native replacement heifers are commonly introduced into herds and are required to adjust to new range and forages. This experiment represents a realistic management situation.

Observations of cattle grazing in this and previous studies indicate that cattle graze independently. They are gregarious in that they graze in the same general area and stay in visual contact with each other but their selection of food appears to be totally independent. There is some evidence that there is little difference in diets of cattle grazing separately and those grazing together in groups (David Balph, personal communication)' ${ }^{1}$. The study pasture supported a very homogenous subalpine grass/forb plant community, thus there was no pattern of grazing patches of plants. We assumed no interaction between animals and considered individual animals as experimental units.

The heifers were transported to the study site at the beginning of the experiment. The native cows grazed the foothills and lower elevations of the mountain for 2 months prior to being trailed to the allotment on top of the mountain. They were selected from the main herd and placed in a small portable corral along with the introduced heifers for 5 days to gentle them and acquaint them

Inimal behavioralist, Wildlife Dept., Utah State Univ., Logan, Utah. 
with the observers. They were all fed alfalfa/grass hay during the 5-day confinement prior to being released into the study pasture.

Diets were quantified by bite count (Bjugstad et al. 1970). Two observers watched cattle daily during the major morning and evening feeding periods. Each animal was observed from a distance of 1 to $5 \mathrm{~m}$ for two 5-minute periods by each observer and the number of bites of each forage class or locoweed plant part was recorded. No attempt was made to adjust for quantity of forage consumed in a bite. The number of bites was used to estimate the proportion of locoweed plant parts in the diet. Analysis of variance (ANOVA) of recorded bites of forage classes was used to determine differences between animal class (native vs introduced), days, time of day, and observers.

\section{Results and Discussion}

The grazing experiment began on $17 \mathrm{July}$ when locoweed was in the late flower stage. Grass dominated cattle diets throughout the study $(>60 \%)$ but no locoweed was consumed until 23 July (Fig. 1).

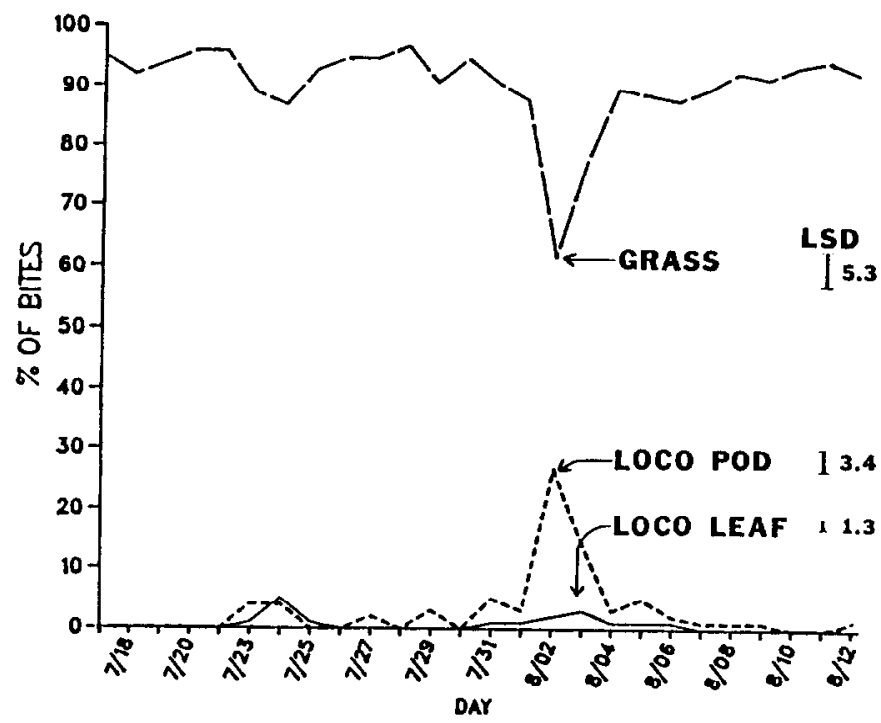

Fig. 1. Mean daily percentage of recorded bites of grass. locoweed pod. and locoweed leaf during 5 -minute observation periods during morning and evening grazing periods.

Two introduced heifers started consuming locoweed pods on 23 July and 1 native cow began selecting pods on 24 July. Storms 18-23 July resulted in $3.8 \mathrm{~cm}$ of precipitation (rain, snow, and hail), and warmer weather following the storm triggered a flush of new grass growth. Most of the cattle stopped consuming locoweed and selected new green grass. Cattle began selecting locoweed pods again on 31 July, and by 2 Aug., all cattle were selecting locoweed pods for an average of $27 \%$ of the recorded bites. Locoweed leaf comprised about $5 \%$ of the recorded bites during this period. Heifers tended to consume slightly more locoweed leaves than the cows $(P=0.08)$. The heifers consumed pods protruding above the plant and then took a bite or two of the leaves before moving on to the next plant. The availability of pods declined and consumption tapered off after 6 Aug. There was no locoweed consumed during the last 2 weeks of the trial. The cattle were placed in an adjacent ungrazed pasture at the end of the trial (26-29 Aug.), but did not select mature locoweed pods. There was no significant difference in consumption patterns at different times of the day, nor were there any differences due to observers.

There was no difference in the amount of locoweed pods consumed between native and introduced cows ( 3.8 and $4.1 \%$ of recorded bites, respectively $P=0.81$ ). There was, however, a significant interaction $(P=0.002)$ between animal class and days (Fig. 2$)$. Two introduced heifers began eating pods on $23 \mathrm{July}$ ( 12 to $50 \%$ of recorded bites). A third heifer and 1 native cow consumed pods on 24 July. The heifers switched from pods to new grass but the

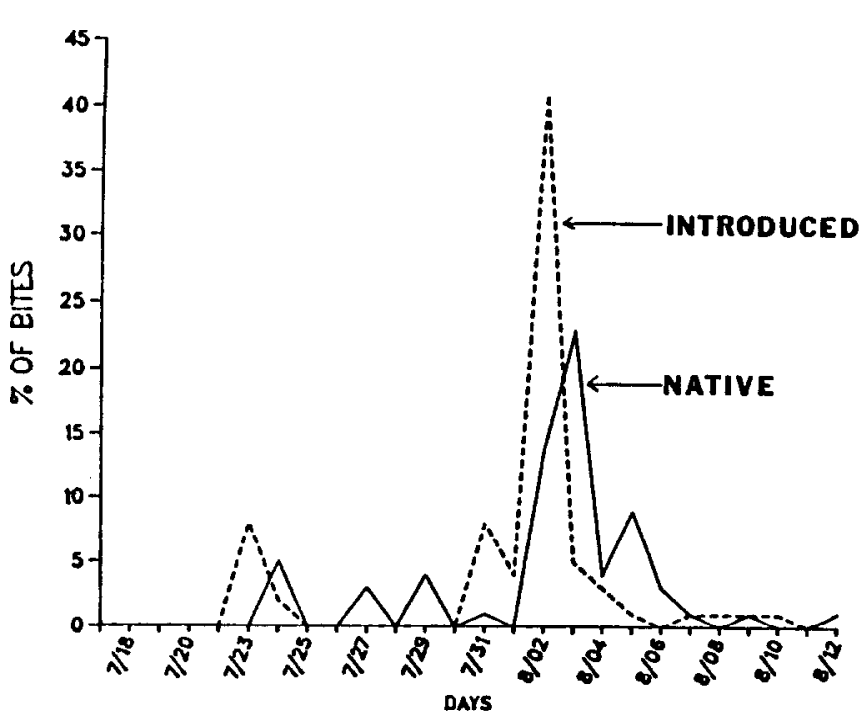

Fig. 2. Percentage of recorded bites of locoweed pods of native and introduced cows.

native cow continued to eat a few pods throughout the interim period between peaks. The same 2 heifers started eating pods again on 31 July ( 25 to $38 \%$ of recorded bites) and all heifers were consuming a substantial a mount of pods by 2 Aug. ( 20 to $68 \%$ of recorded bites). Two more native cows started eating pods on 2 Aug ( 8 to $18 \%$ of recorded bites) and all native cattle were eating substantial amounts of pods by 3 Aug. Although recorded bites of locoweed pods were extremely high for the introduced heifers on 2 Aug., consumption fell below 5\% of recorded bites for the remainder of the peak consumption period. The native cows had a longer period of time in which recorded bites ranged between 5 and 23\% of recorded bites. Availability of pods probably did not influence heifers to reduce consumption after 2 Aug. Pods were sufficient to support consumption by native cows for several more days.

The average percentage of recorded bites of locoweed pods during the 7-day period of heavy locoweed consumption (31 July to 6 Aug.) was $8.0 \%$ for introduced heifers and $7.5 \%$ for native cows (Table 2). The range in recorded bites among individual cows

\section{Table 1. Standing crop (kg/ha) of forage classes at 4 intervals during the grazing season, standard error (in parenthesis), and forage disappearence between sampling intervals.}

\begin{tabular}{lcccc}
\hline \hline & $\begin{array}{c}\text { July 16 } \\
\text { Beginning }\end{array}$ & $\begin{array}{c}\text { July 31 } \\
\text { Early pod }\end{array}$ & $\begin{array}{c}\text { Aug 13 } \\
\text { Pods gone }\end{array}$ & $\begin{array}{c}\text { Aug 26 } \\
\text { End }\end{array}$ \\
\hline Grass & $1042( \pm 76)$ & $502( \pm 75)$ & $378( \pm 68)$ & $279( \pm 47)$ \\
Forb & $822( \pm 100)$ & $301( \pm 32)$ & $244( \pm 48)$ & $176( \pm 18)$ \\
Loco leaf & $235( \pm 59)$ & $102( \pm 43)$ & $50( \pm 16)$ & $102( \pm 25)$ \\
Loco head & $53( \pm 13)$ & $53( \pm 23)$ & $11( \pm 5)$ & $8( \pm 7)$ \\
Total & 2142 & 958 & 683 & 565 \\
Disappearance & \multicolumn{2}{c}{1194} & 275 & 118 \\
\hline
\end{tabular}

was $5.7 \%$ to $12.2 \%$ for the introduced heifers and $3.9 \%$ to $16.1 \%$ for the native cows. Thus, total locoweed pod consumption during this period was similar between the 2 groups.

The failure of the heifers to continue a high level of locoweed pod consumption when pods were readily available suggests that there was no real lasting preference of the pods exhibited by the heifers compared to the native cows. Curiosity may have influenced the introduced heifers to select pods earlier in their developmental stage, but the relative time when pods were consumed and the total consumption of pods were similar. There is insufficient evidence to conclude that inexperienced introduced heifers are more inclined 
Table 2. Mean percentage of recorded bites (\%) and standard errors (SE) of individual animals during the 7 diny peak consumption of locowred (July 31-Aus 6).

\begin{tabular}{lccc}
\hline \hline Class & $\begin{array}{c}\text { Individual } \\
\text { Animal }\end{array}$ & $\begin{array}{c}\text { Locoweed } \\
\text { Leaf }\end{array}$ & $\begin{array}{c}\text { Locoweed } \\
\text { pod }\end{array}$ \\
\hline Introduced & 15 & $4.6 \pm 3.0$ & $\%$ SE \\
heifers & 20 & $3.3 \pm 1.6$ & $12.2 \pm 7.0$ \\
& 23 & $0.8 \pm 0.7$ & $7.2 \pm 6.1$ \\
Average & 26 & $1.2 \pm 0.5$ & $7.0 \pm 4.6$ \\
Native cows & 1 & 2.5 & 8.0 \\
& 2 & $0.2 \pm 0.2$ & $5.7 \pm 3.2$ \\
& 3 & $1.1 \pm 0.7$ & $3.9 \pm 1.3$ \\
Average & 4 & $0.04 \pm 0.04$ & $4.4 \pm 2.4$ \\
& & $1.4 \pm 0.8$ & $16.1 \pm 7.2$ \\
& & 0.7 & 7.5 \\
\hline
\end{tabular}

to consume white locoweed on this range and become intoxicated than are native cows. Locoweed poisoning is a chronic type of intoxication requiring a fairly large intake over an extended period of time to show signs of poisoning. There were no signs of intoxication among the experimental animals. However, feces became loose and watery during the period the cattle were consuming locoweed.

Total standing crop when cattle were consuming locoweed pods was $958 \mathrm{~kg} /$ ha (Table 1). Enough grass was available that grazing pressure alone would not have forced animals to switch to the locoweed pods. Total standing crop at the end of the trial was 565 $\mathrm{kg} / \mathrm{ha}$, which represented $74 \%$ utilization. Furthermore, grass and most other forbs had senesced. The low nutrient content of senescent grass, combined with its relatively low availability, was still not sufficient to cause cattle to select the relatively abundant and green locoweed leaf.

Addiction to locoweed reported in the literature (Marsh 1909, James et al. 1968, James and VanKampen 1969, Peters and Sturdevant 1908) was not apparent in this study, nor in the previous intensive locoweed grazing study (Ralphs 1987), although locoweed pods contained moderate levels of the toxic alkaloid swainsonine (Ralphs et al. 1986). If there were addictive properties, the steers in the previous trial and the cows in this trial would have been expected to continue grazing the abundant locoweed leaves after the immature pods were exhausted, or to consume mature pods when placed in a fresh pasture.
This study supports the results of the previous intensive grazing study (Ralphs 1987) that white locoweed seed pods are palatable and voluntarily selected by free-ranging cattle during the normal grazing season.

\section{Literature Cited}

Arnold, G.W., and M.L. Dudzinski. 1978. Ethology of free-ranging domestic animals. Elsevier Scientific Publishing Co., New York.

Bjugstad, A.J., H.S. Crawford, and D.L. Neal. 1970. Determining forage consumption by direct observation of domestic grazing animals. In: Range and Wildlife Habitat Evaluation-A Research Symposium. USDA Forest Serv. Misc. Pub. 1147.

Everist, S.L. 1981. Poisonous plants of Australia. Angus \& Robertson Publishers, Sydney.

James, L.F., K.L. Bennett, K.G. Parker, R.F. Keeler, W. Binns, and B. Lindsay. 1968. Loco plant poisoning in sheep. J. Range Manage. $21: 360-365$.

James, L.F., W.J. Hartley, K.R. Van Kampen. 1981. Syndromes of Astragalus poisoning in livestock. J. Amer. Vet. Med. Ass. 178:146-150.

James L.F., W.J. Hartley, K.R. Van Kampen, and D.B. Nielsen. 1983. Relationship between ingestion of the locoweed Oxytropis sericea and congestive right-sided heart failure in cattle. Amer. J. Vet. Res. 44:254-259.

James, L.F., and K.R. Van Kampen. 1969. Locoweed (Astragalus lentiginosus) poisoning in cattle and horses. J. Amer. Med. Ass. 155:525-530.

Marsh, C.D. 1909. The locoweed disease of the plains. USDA Bull. 112.

Marsh, C.D. 1916. Prevention of losses of livestock from plant poisoning. USDA Farmers Bull. 720.

Molyneux, R.J., and L.F. James. 1982. Loco intoxication: Indolizidine alkaloids of spotted locoweed (Astragalus lentiginosus). Science 216:190191.

Molyneux, R.J., L.F. James, and K.E. Panter. 1985. Chemistry of toxic constituents of locoweed (Astragalus and Oxytropis) species. p. 266-278. In: A.A. Seawright, M.P. Hegarty, L.F. James, and R.F. Keeler. (eds), Plant toxicology. Queensland Poisonous Plants Committee, Yeerongpilly.

Peters, A.T., and L.B. Sturdevant. 1908. Locoweed poisoning in horses. Neb. Agr. Exp. Sta. 21st Annu. Rep. p. 74-105.

Ralphs, M.H. 1987. Cattle grazing white locoweed: Influence of grazing pressure and palatability associated with phenological growth stage. J. Range Manage. 40:330-332.

Ralphs, M.H., L.F. James, and J.A. Pfister. 1986. Utilization of white pointloco (Oxytropis sericea Nutt.) by range cattle. J. Range Manage. 39:344-347.

Van Kampen, K.R., and L.F. James. 1970. Pathology of locoweed (Astragalus lentiginosus) poisoning in sheep. Path. Vet. 7:503-508.

Van Kampen, K.R., R.W. Rhees, and L.F. James. 1978. Locoweed poisoning in the United States. In: R.F. Keeler, K.R. Van Kampen, and L.F. James (eds.), Effects of poisonous plants on livestock. Academic Press, New York. 